Kelly, John (2018): Dilemmas of Belonging in Fiji, Part II: Shanti, Swaraj, and the Problem of Political Armies. In: Elfriede Hermann and Antonie Fuhse (eds.): India Beyond India: Dilemmas of Belonging. Göttingen: Göttingen University Press (Göttingen Series in Social and Cultural Anthropology, 12), pp. 99-130. Doi: 10.17875/gup2020-1266

\title{
6 Dilemmas of Belonging in Fiji, Part II: Shanti, Swaraj, and the Problem of Political Armies
}

John Kelly

\author{
"Societies hide the pain of belonging." \\ McGranahan (2010: 3), citing Das (1995)
}

\section{Belonging to What?}

Dilemmas of belonging: our volume's theme poignantly captures the situation of all too many peoples in the diasporas of the postcolonial world. As Martha Kaplan's chapter has made clear, the dilemmas of belonging to post-colonial nation-states reveal the real limits to the utopian prospect of liberal self-determination. Especially for some people, like those in India beyond India, the diasporic South Asians? Clearly. But can their experience illuminate issues larger than that experience? Are there dilemmas of belonging only for some people, or for all? And what shall we investigate further, to better understand dilemmas of belonging? Writing for peace during what we now know as World War One, Thorstein Veblen ([1917] 1998) observed that advocates for peace were always persuasive, yet the world plunged into ever more devastating wars. "What Shall We Say?" he then asked (typically garishly, with the quotation marks and the capital letters). His answer will help us with our own, as we seek insights into politics responsive to changing situations, but also deeply rooted in cultural valuations, precisely the stuff of politics beyond primordialism and instrumentalism. And Fiji as experienced by Indo-Fijians can help us as we seek 
to track the emotions of belonging in their historical connections to reasons of state, nation, religion, and all other precedent relevant realities. ${ }^{1}$

Let us start where Kaplan (this volume) left us, among Fiji's realities, and thus among things on earth not dreamed of in Versailles's philosophies. Kaplan's account tracks a legal and social history for all people in Fiji, somewhere well beyond and far more complicated than any story of a single group's "self-determination." Yes, by the time of Fiji's decolonization there was a clear template for nation-state law and order. Independent Fiji began with a constitution. And that constitution began with a preamble in the voice of "we the people." But Fiji's constitution was actually delayed by six months in London's colonial office because the constitution drafters there were working through contradictions in Jamaica's document. And, the exiting British did not meet local requests for drafts translated into Hindi and even Fijian language for perusal before its adoption in London and Fiji (Kelly and Kaplan 2008). Further, Fiji's document was unusual among postcolonial constitutions: it found sovereignty to begin not with the decolonization struggle but rather in a chain of custody marked from the Deed of Cession, wherein Fijian chiefs recognized the British Crown as sovereign, construed as "giving" the British a sovereignty now coming back to the islands (Saunders 1997). Fiji's independence constitution thus ambiguously always locates sovereignty, finally, with the Fijian chiefs. Acts of election then enter democratic representatives of the people - any and all people, whether in ethnically delineated districts or national districts - merely into power-sharing with others always already there (a status that also includes the police and military, of course, in every actual nation-state). Kaplan shows the difference real hierarchy makes for citizenship, the pessimal ${ }^{2}$ disposition necessary for Indo-Fijians to belong comfortably to Fiji as their place, and the grim alternative of renewed diaspora against increasing hostility to migration. We can carry her discussion further both by exploring a specifically Indian dilemma of virtue and reconsidering those valuations within more global dialectical tensions. The dilemma of virtue is that between shanti and swaraj, shanti meaning peace, swaraj self-rule (and 'a dilemma of virtue' meaning, whether to define the situation, to valorize or even transvalue possible courses of action, in one light or the other). ${ }^{3}$ The global backdrop, then, is dialectical tensions not only

\footnotetext{
${ }^{1}$ Stanley Tambiah (1996) is my primary source for insistence on the wisdom of taking political anthropology beyond both primordialism (as, for example, in cultural template arguments, people respond as culture wires them to) and instrumentalism (as, for example, in rational choice arguments, which naively extend the chronotope of choice while they extend reckoning to cover all thinking). From William Mazzarella (2013) comes inspiration for insisting on the wisdom of connecting reason and emotion in all actual depictions of human action. All of this commits to Marshall Sahlins' (1976) view of culture encompassing and informing not-so practical reason, and above all extends the problem of the history of culture into the realm insisted upon by Veblen ([1917] 1998), situations with violent (in game theory terms, coercive and compelling as well as would-be persuasive) states already constituting irreducible parts of social situations, limits and opportunities.

${ }^{2}$ I will discuss pessimalism in the next section.

${ }^{3}$ People actively engage with the core values of their culture, and cultures set and change their priori-
} 
about equality and justice in theory and reality, but also about organized violence, peace and right. Fiji, with its frontstage chiefs and (usually, but not recently) backstage military, and changing relations between the two, Fiji with its complex engagements of both with Indo-Fijians, Fiji can show us the sometimes implications of two less frequently reckoned dimensions of nation and citizenship. The first, that Veblen emphasized, is the situating precedence of states and their organized violence over nations and their claims of right. The second, the more frontstage problem after all for belonging in Fiji, is the sometimes appearance, within nation-states, of political armies. Political armies claim themselves to be the conduit between nation and state - the nation in the state, legitimate and sovereign - by uniquely embodying national will at time of need. In Fiji's case, the army after the first three (or four; cf. Kelly and Kaplan 2001b, ch.6) coups legitimated itself as the expression of the needs and will of an ethnically exclusive inner and sovereign nation. By its roots and acts, the army embodied the taukei, owners of the land, and was the servant of chiefs, sovereigns. In the latest, 2006 coup, the powers of state before nation became most clearly and strangely visible, as the army proved able to disassemble all other institutions before it could delimit itself, and even the Great Council of Chiefs found itself outside of the new realms of law and order.

\section{Shanti and Swaraj}

The extraordinary public responses to coup violence in Fiji have been led by insistence on peace, centered in the Indic, Islamic, and especially devotional Hindu value of shanti. Shanti is a broadly, soteriologically valorizing concept of peace as sign and destiny of the truly good in a world of suffering. The extension of the ethnic Fijian conception of mana to valorizing the usurpations of the coups has not launched spiraling violence, ethnic or otherwise, because the counterweight of shanti has kept the peace in the face of aggressive assertion and testing. Elsewhere, Kaplan and I (Kelly and Kaplan 2001a, Kelly 2005, 2011) examine in more detail the "intimate enemy" dynamics that have opened a cultural dialectic between mana and shanti in Fiji. Here, let us hone in on the emergence of a transvaluing shanti amidst the dilemmas of belonging faced, across many decades, by the South Asian migrants who became the Indo-Fijians. Dilemmas of belonging will seem, and feel, different if one is in quest of peace, than if one is in quest of justice, or in quest of mana, or of selfdetermination. While Americans have veered, across the long 'American Century,' between Wilsonian views of self-determination as good policy, toward views of the quest for self-determination as inevitable expression of free human nature, and back to the concept of best policy, variously placed Indo-Fijians have relied on strikes and

ties, when people are faced with dilemmas in which virtues lie on both possible courses of action, and with narratives variously situated that recommend solutions. Ruth Benedict pioneered the concept in the tenth chapter of The Chrysanthemum and the Sword (1946). See also Kaplan's chapter this volume. 
withdrawal to seek justice and peace even before the electric news of Gandhi's successes. They have since debated the core values of social and political life from various places and positions, with a strong sense both of global trends and local distinction, usually understood as local limitation, especially if the goal is self-rule.

The Hindu value of shanti, emotional peace in the face of hardship and suffering, has come to be of great importance to many Indo-Fijians, whether or not they come to feel that they belong in, or even to, the islands of their birth. Shanti, a cardinal emotion of bhakti or devotional Hinduism, is the virtue of pessimal transacting with God - peacefully accepting whatever God gives with all attendant confidence and hope in eventual good and love. The bhakti marg of sanatan dharm, which is to say, the devotional path within the eternal dharma, enables grace within alienated labor, and acceptance of one's own good and right even when a lifetime will not see its just deserts realized. This confidence in divine love and in more ultimate hope is different from a Christian call for redemption from sin. In Fiji's emerging moral economy, Indo-Fijian shanti and grace in alienated labor has both complemented and contested ethnic Fijian fears of alienation and pursuit of mana and loloma, power and Christian love. Shanti has been a circuit breaker when 'coup culture' overturns democracy in the name of Fijian chiefly mana, even when the results have led Fiji Hindus and Fiji Muslims to doubt the wisdom of belonging to the islands, and especially to the locating of children and grandchildren there.

Yet all these considerations, these profound interactions of culture and law within postcolonial political dialogue, have still only examined part of what the Indo-Fijian dilemmas of belonging to Fiji can teach us about the postcolonial nation-state. Kaplan has detailed how legally-ensconced hierarchy in land laws, electoral laws, and public culture can place real limits onto the utopian deep, horizontal comradeship of the nation-state. Shanti, with its pessimalism ${ }^{4}$, fits the situations of many of the postcolonial labor diaspora colonies much better than either the knowledge-focused, self-help purification movement of the Arya Samaj, or the confidence of self-determination liberalism, explaining why a bhakti-centric Sanatan Dharm movement was more successful than the reformist Arya Samaj in so many labor diaspora colonies across the twentieth century. ${ }^{5}$ Prospects for shanti were obviously relevant, but also

\footnotetext{
${ }^{4}$ Pessimalism is a transaction strategy in which you take what you can get, rather than minimizing, maximizing, or seeking to optimize by negotiating one's terms of transaction, in the model originally pioneered for South Asian culture of exchange by McKim Marriott (1976). Shanti devotional world view tends to treat Hindus in this the kali yug, or fourth- and final age in a devolving, corrupting universe, as moral kin to Sudras, the low, service castes when society was better organized. Sudras by their own actions become too polluted in substance to succeed on the path of knowledge or jnana marg. All are equal in dependence on God's grace, love and generosity to succeed, and the wise among them embrace this situation. Thus, the ethic to pessimal transacting, taking whatever comes one's way, relying on God and not self for outcomes.

5 The most famous diaspora discourse emanating from one-time labor colonies, ironically, occludes this key point; in fact it is precisely what V.S. Naipaul 's (1999) modernism seeks to overcome. Naipaul, in his alienation from his Indo-Caribbean roots (and citizenship) in both his life and works shows
} 
prospects for swaraj, peace and also self-control, each sometimes seen as means to the other. In Fiji, land of shanti and mana, what about that latest, largest coup, whose transfigured mana, if it can even be considered such, led to the disbanding of the Great Council of Chiefs itself? What is to be done, if you quest not only for shanti but also swaraj, not only peace but also self-rule, in confrontation with political armies claiming sovereignty over you?

Pessimalism can only be a tactic, and probably a doomed tactic, if one's ultimate goal is not merely shanti but swaraj, not only peace but self-rule. And vice versa, insistence on swaraj can be considered a useful tactic sometimes, but it is ultimately doomed and unpeaceful, in the real world, if one abandons Gandhian self-rule and/ or American self-determination as the ultimate end. Ahimsa, non-violence, becomes more than a tactic if shanti, peace, is the end, as well as means. This chapter seeks to situate Indian diasporic dilemmas of belonging, whether to belong in, even to, Fiji. Ultimately, the chapter will be about war, peace, and political belonging generally. But proximately, and first of all, it is about how, for many Indo-Fijians, the dilemma of virtue between shanti and swaraj vitally sets the question - to stay, or to go - and on what terms.

Swaraj encompasses, roughly, the prizing of rights, duties, justice and uplift, above all via self-control, 'self-rule.' Two ethnographic vignettes will illustrate how shanti and swaraj can come to be in tension, before we return to the most general questions of theory. First, in 1985, in other words, before any coups in Fiji (yet shadowed with inchoate awareness of what was coming; see also Bharati 1972 on Uganda), an old man arrived late to a Ramayan mandali in Ra Province on Viti Levu (Fiji's 'big island'). Ra district is predominantly ethnic Fijian, with population thin on the ground, the edge of decent cane-growing territory. Ra's Indo-Fijians are farmers - hardy but mostly not prosperous. A very good motive for persisting there in the suffering cane economy was after all desire for shanti-a peaceful, rural life. Ramayan mandalis (mandali is related to mandala, but really just means circles) are evenings devoted to collective singing of bhajans, devotional hymns set to themes from the Tulsi Das, Hindi-language Ramcaritmanas, a bhakti devotional rendition of the Ramayana story put at the center of Sanatan Dharm ("eternal tradition") style Hindu-

the successive alienation, an Arya Samajist father rejecting a Sanatani, much more folksy grandfather, leading to a grandson whose path of knowledge walked away from belief altogether, to firmly reorient toward modernist, individual self-emergence. Here we will not pre-emptively model all of diaspora as self-determination according to scale and location of place, as if one is merely to choose whether to be Indian writ global, or member of some more lately joined nation, or a free sojourner in this world somehow otherwise construed - and in the end, imagine people oriented solely to a secular future, an immanent temporal redemption. Modernism does have a strong constituency among Indo-Fijians, often combined with other valorizations of place and time. Both because those other valorizations have, I think, the outsized impact on what makes Fiji's history different, and to resist modeling that contrasts Fijians' cultural vibrancy with Indian instrumental calculating, here we explore the Fiji situation with South Asian, with the population especially South Asian Hindu, cultural commitments also in mind. 
ism. ${ }^{6}$ The old farmer joined the bhajans, and afterward in quiet conversation was apologetically agitated. Why was he upset? Youth from a Fijian village (koro) threw stones at his car as he drove quickly past in the dusk. Yes, he was in a hurry, but why did they break his truck's back window? What was their motive? Varieties of bored, resentful, and deluded hatred were suggested, but the old gentlemen (in all senses deserving the term) cut off assessment, firmly apologizing, again, for this existential disruption of their quest for devotion-oriented peace. Even when another member of the circle raised the question whether Fiji was making it impossible to seek shanti, he firmly resisted. He was not going anywhere, and windows could be fixed. Resenting his own, unsettling, resentment, his irritation was above all not about the injustice of this assault on his property but on the interruption of his own flawed pursuit of shanti, and he was all too aware that restoring calm was in crucial part up to him. His own self-control was to serve the pursuit of peace, not only vice-versa.

This gentleman's depth of commitment to seek shanti was marked; thus I remember it; others would no doubt have responded differently. Indo-Fijian memory is much about assessing varieties of response to different types of violence. Its existential tinge clearly goes back to girmitiya, indentured laborer days, and the fateful decisions whether to stay in Fiji, as $60 \%$ of surviving indentured laborers chose to do, or return to India, as $40 \%$ did, often at great expense and real hardship. We will next look briefly at Totaram Sanadhya's Story of the Haunted Line ([1922] 1991), perhaps the most famous iteration of indenture-line dilemmas. The hero of Sanadhya's story was forced to live in an abandoned, reopened "line" or plantation housing shed, a line thought haunted by former suicides. He was starving, one night, after acts of generosity had depleted his food supply. He came very close to suicide himself, standing on a stool with a noose around his neck, before a heterogenous set of simultaneous intercessions saved him. The causality was ambiguous. After a prayer to the Goddess for rescue from his longing and suffering, when memory of his mother was triggered by recognition of his duty to her, there was a knock on his door. Stepping down from his stool, opening his door, the hero met ethnic Fijians, not ghosts. They had returned, in the cool of the night, with large gifts of root crop food, in generous return on a perforce scanty meal of rice he had provided them earlier in the week, with the last of his week's food ration. At Fiji's independence, in the most optimistic of moods, efforts were made via stage play and even film to make this Story of the Haunted Line a paradigm for future recognition and exchange between

\footnotetext{
${ }^{6}$ I have written elsewhere (Kelly 2001) in detail about the Arya Samaj reform movement and its rationalist, reformist knowledge-path (jnana-marg) Hinduism, its early success in Fiji building schools and leadership structures, later overcome by bhakti-marg, i.e. devotionally oriented Sanatan Dharm missionaries, who persuaded the majority of Fiji Hindus to adopt the Ramcaritmanas as the perfect shelter for Hindus suffering the exile of labor diaspora. Thus shanti in the shelter (sharan) of devotion to Ram via this text is a particular soteriological goal of many Fiji devotional Hindus, as well as a widespread worldly value orienting (sometimes, often, or even always) the deontology of many more people there. Ramayan mandali meetings, depending upon (often revolving) leadership (as circles) sometimes involve reading and interpretation of Tulsi Das passages, but always the singing of bhajans.
} 
ethnic groups. In its chastity and generosity this story wrote over many dilemmas on the ground in actual girmitiya history, concerning Brahmins, caste, gender, sexuality, and kinship. But the point, for us here, is the way the story focalized (in Tambiah's sense, see Tambiah 1996, discussed below) the dilemmas themselves: this "Story of the Haunted Line" has justly become a paradigm of how to move forward in exile, addressing violence and fear of violence, hunger and shame, memory and duty, devotion in despair, humility and its rewards, and even life and death itself. This core dilemma is not so much to be or not to be, since the story presumed his soul would continue some way, but how to respond to extreme suffering.

And how does this dilemma, the quest for shanti or swaraj, look outside of Hindu parable? The moralization of pessimalism (this strategy of accepting all that is offered) can be reconsidered if we remove sanguine hope for divine reward, as something much like what a Californian philosopher (James 2017) has recently called "adaptive attunement." This adaptive attunement, argues James, is free will reconsidered (and Jean-Paul Sartre's ([1957] 1968) existentialism reconsidered) to be compatible with a deterministic universe, imposing will not by controlling things but by efficient and purposeful alignment to them. A politics and ethics of extreme acceptance can be theologically optimistic. But under what conditions is it practically, let alone ethically, sufficient in the human political world? There is a problem of possibility here that needs to be further explored, crucial to the dilemmas of belonging. Dialectical tension between shanti and mana has emerged in Fiji, a new, fraught, trans-ethnic political culture in which chief-like self-justifying domination is delimited by withdrawal, non-participation and avoidance, a dialectic that has been as productive as it has been frustrating for all who stay there. But can it sustain peace, let alone anything comparable to the ideal of liberal democratic self-rule? It is unwise to underestimate successful assertions of mana in Fiji's 'coup culture.' But perhaps, as we shall see, it is even more unwise to neglect the more global history of postcolonial state violence.

\section{A New Kind of Militarism in Fiji, amidst Global Problems for Self-Determination}

Fiji's current military-backed government is different from Fiji's previous coup governments. It is stranger, less positioned in the ethnic landscape and unstuck in ideology, professing respect for global standards of equality and democracy, ratified by a closely controlled election in 2014 , but more generally, for more than a decade now, forbidding most kinds of political discourse and action. Fiji's current regime is extremely strange. However, the failure of Fiji to thrive as a self-determining nationstate is all too typical. The mid-twentieth century promise of decolonization has led not to the realization of a globe of peaceful, free, prosperous democracies but to increasing asymmetries and smoldering, increasing violence. Neoliberal pressures from capitalist centers in Europe and the United States, the so-called Washington Consensus, overwhelmed efforts to organize a counter-ideology. Yet it seems also to 
have generated even in Europe, and certainly globally, the uneven field of diffuse resentments and restlessness that Appadurai (2006) has aptly named "the geography of anger." This development has global roots. A key nexus for both the positive and the negative, for both political constitution, and this shadowing anger, is the 1955 Bandung Conference. What African-American novelist and social critic Richard Wright said of the delegates to the Bandung conference could aptly be said, now, of the vast congeries of global skeptics of the neoliberal institutions of the new world order: "They were much clearer about what they did not want than about what they wanted" ([1956] 1995: 212). At Bandung, what they did not want was continuing interference from ex-colonizers. The call for the conference began with the question posed by Ali Sastroamidjojo, Prime Minister of Indonesia, at the 1954 Colombo conference, when five Asian prime ministers there pondered why the fate of IndoChina was being settled, instead, at a simultaneous conference in Geneva: "Where do we stand now, we the people of Asia, in this world of ours today?" (Weeraratna 2014). Our contemporary geography of anger might well, still, concern the failures of mobilizations of "we, the people," many places, to realize peace, prosperity, and justice. And while Fijis current rulers might be said to be clear about what they want, if we take them at their word that they wish to join the neoliberal world and to end many of Fiji's experiments with communal exceptionalism in voting and governing, we still have to observe two things. First, they are late to a party that is not shaping up as its organizers planned. Second, their means bear little relationship to their ends. If Fiji's current rulers do know what they want, they certainly do not know how to get it.

We seek to understand Fiji's political extremes, both because we want insight into Fiji itself, even possibly grounds and lines for hope for politics there, and also because Fiji, in its extremes, might clarify some of the structures of the new global order of nation-states, emergent in decolonization after World War II. Fiji might help explain our global failure to meet the high expectations that decolonization into nation-states once entailed. Its study might make us wiser in the engineering of new hopes and expectations more globally, especially about belonging and its dilemmas in a world increasingly built by diasporic connections and movements. The Indian National Congress, with real wisdom, spent much of the twentieth century urging Indian labor diasporic communities not to return to India: exactly what, where, will constitute wisdom for India beyond India in the twenty-first century?

Fiji's politics are surprising by many measures, especially when considered in combination. Fiji was extreme among new nations in the symmetry presented by its major ethnic populations, ethnic Fijian and Indo-Fijian, shortly after independence, close to a 50/50 population split. Fiji has also been extreme in the intolerance of one of the two groups to government by the other, with ethnic Fijian-backed coups following just one month (in 1987) and one year (in 2000) of government by IndoFijian backed parties, within a long century of democratic or partially democratic government, with never a military move in the other direction across unbroken decades of ethnic Fijian overrepresentation and dominance. But Fiji is also extreme, 
and this is perhaps the key extreme, in the non-violence of its coup culture, with only one solitary death by military violence across five coups. Extreme in symmetry of ethnic divide, in one-sided political domination, and in non-violence. But in other ways, the problems of the nation-state in reality in Fiji are not extreme at all. Fiji is squarely among the majority of new nations engineered in the decolonization era that have, as Ranajit Guha put it speaking of India, 'failed to come to their own' (Guha 1982: 7) (or as an American would say, 'failed to come into their own'). The failure of most of these new nations to find freedom, peace and prosperity by way of their exercise of self-determination has frustrated utterly the planners, and even more the denizens, of the new world order after World War II. In fact, in its peacefulness, in its prosperity, and until recently in its civil freedoms Fiji has done much better than most, though it suffers now on all three measures.

The ethnic symmetry in Fiji is more complicated, historically dynamic and politically hedged than is convenient for consociational democracy planners. Consociational modeling would be simpler if ethnicity was some kind of natural historical phenomenon independent of specific historical engagements and movements. Structuring institutions for communal sharing is vastly harder when we recognize labile social, cultural and legal histories. As Kaplan's chapter explains, at Fiji's independence in 1970 , the Indo-Fijians were actually $51 \%$ of Fiji's population. But the British designed constitution gave them only $40 \%$ of the communally designated parliamentary seats, not an insignificant shift in a democracy. The departing British, in negotiation especially with their Alliance Party successors, built into Fiji's first independent constitution further asymmetries against the ordinary liberal design expected in republican government. These included appointed Senate seats for the quasi-aristocratic ethnic Fijian Great Council of Chiefs, and also control by those Great Council appointees over a wide swath of law governing land ownership and regulation of ethnic Fijian social life. A third asymmetry was overrepresentation in parliament of people neither Indo-Fijian nor ethnic Fijian, the 'general electors,' who were originally, prominently, the Chinese- and European-descended citizens of the new nation, but who over recent decades have come to be mostly people of mixed, part-European ethnic descent, and other Islanders resident in Fiji, as most of the Chinese and European citizens have migrated out. Over time, every decade since independence, all of Fiji's demographics have shifted significantly. Consonant with the rise of 'other Islanders' among the so-called 'general electors' has been an increase in the proportion of the overall population that is ethnic Fijian, an accelerating trend caused both by higher ethnic Fijian birthrates and a large outmigration of IndoFijians, an outmigration especially of the educated and skilled that in its numbers, if not in its proportions, has paralleled and overmatched the rejection of Fiji by its initial Chinese and white citizens. The population has, in a history very brief for such significant demographic shifting, gone from an absolute Indo-Fijian majority to parity to an absolute ethnic Fijian majority at present. Overall, Indo-Fijians have been surprisingly sanguine about this trend, particularly puzzling in light of the history of transgression of Indo-Fijian social and political right. In my experience, Indo-Fijians 
often hope that an ethnic Fijian majority will work as a tactic against violence, to lessen fears and calm roiled political and social waters (Kelly 1998). Readers of Susanna Trnka's vivid ethnography (2008) of post-coups Indo-Fijian life will know that Indo-Fijians have long lived in fear of ethnic Fijian violence. While deaths have been rare to non-existent, crimes against property have been all too common, and the justice system is often lenient when the vector of the crime is ethnic Fijian and poor against anyone wealthy. Strong physical barriers to protect private property became the middle class and upper class norm in Fiji, especially as the decades of coups have unfolded.

Fiji's surprises and extremes can show more when compared to other complex realities than when measured against an ideal type of normal governance. To put this differently, Fiji is not simply a successful, a normal, or a failed state. Fiji's troubles are part of the failure of a global nation-state system. Multiple, partial, all too common, and increasingly general failures of the theory of self-determination in reality, I think, are the cardinal problem for the political anthropology of our times. Many of these problems are well known. One of the best sources for contemplation of them is the magisterial review of UN declarations, protocols and treaties compiled by Brij Lal and others in the 1996 Fiji constitutional review document, Towards a United Future (Reeves, Vakatora and Lal 1996). Other problems are more obvious in reality than theory, notably the prevalence of political armies, military governments as an alternative grammar to the relationship of nation and state, and/or states in perduring military occupation of part or even all of their citizenry, with or without such a legitimating 'political army' (sometimes legitimacy depends on who you ask). Here, some new comparisons may be rewarding. Many modes of comparative study of Fiji's politics have already been fruitful: much has been gained by comparing Fiji to other Pacific Island histories, as Stewart Firth (2000), for example, has brilliantly shown, along with many others including Doug Munro (1990), Epeli Hau'ofa (1993), and Nicholas Thomas (1991). The comparison of the indentured labor colonies of the British Empire has its own political and social stories to tell, with insights in particular from Brackette Williams (1991), and much to be learned from the ethnographies of Thomas Blom Hansen (2012), Viranjini Munasinghe (2001), Aisha Khan (2004) and others. The questions of racism and communalism in Empire have drawn many to compare the political duality in Fiji with that of South Asias Hindu/Muslim politics and the traumas of partition (see also Kaplan and Kelly 2017).

A different comparison will highlight different local and global patterns. Especially because of the increasing role, and increasing strangeness, of Fijis military in government, let us compare Fiji's political trajectory to that of the part of our planet that has been most persistently dominated by military government in the era of decolonization. That is the Asian Highlands. 


\section{Highland Asia's Endless Warfare: India's Other Decolonization Trauma, and What Nehru Found "Absurd"}

Compared to military incursions in many locations in Asia's Highlands, Fiji's coups are small affairs. Afghanistan is now deep into its second decade of US counterinsurgency occupation, and that after a decade of US-backed war against Soviet occupation engineered by Pakistan's Directorate of Inter-services Intelligence (ISI), and then the rise of the Taliban. Death tolls from militarized conflict in Afghanistan since World War II are in the millions, and military conflict has disrupted everyone's lives. Pakistan, too, has lived a heavily militarized and violent half century, its own highlands held in amber in striking continuation of British colonial indirect rule policy, and simultaneously managed as a conduit for the episodically continuing warfare in Afghanistan and Kashmir. Before supposing that the military conflicts of the Highlands are somehow determined by Islam and jihad, notice the episodically raging and simmering conflicts, also, in Tibet, and the struggles in Nepal (the only major independent nation-state in the Highlands) and the fifty years of Indian army occupation in Northeast India, where twice as many people have died in counterinsurgency occupation violence as have died in Kashmir. I am unaware that anyone has the full story on violence, conquest, and social reorganization in Yunnan. From the days of the Long March through its sudden prominence for Chiang Kai-shek and the Burma Road in World War II, Yunnan transformed from a sleepy outback into a strategic conduit. And meanwhile the extraordinary unraveling of Burma's democratic order, its civil wars and long military dictatorship changed utterly what the Burma Road offered China, though China clearly has never forgotten or given up on its plan for Burma and commercial development. If everything from Tibet to Burma is evidence against blaming Islam for highland political strife, highland Burma's story among many should caution us, also, against ascribing highland struggles mainly to the Cold War or other larger geopolitics. Let us track the rise of military government in the era of nation-states by considering the region with so many, from Afghanistan and Pakistan and Kashmir to Tibet, Nepal, and Yunnan, to Northeast India and Burma. While religious conflicts and Cold War proxy-fighting will be important, we have another story to unearth in this long and sad history: to put it simply, and oversimply, the fate of tribes in the era of nation-states. Without a quasi-evolutionary view of the tribal as primitive (in contrast, e.g., to Ahmed 2013), Fiji's fate hinges on the category itself, and a unique extreme sympathy. Fiji was shaped and is still path-dependent on a unique British sympathy for the people they saw as tribal, a sympathy sufficient to justify precedence for Fijian chiefly claims of sovereign right. Why did colonial Fiji insist on what Nehru found "absurd"? Let us seek to understand this strangeness in Fiji amidst the devastating ubiquity of military occupations more generally.

Consociational democratic theorists often point at India's partition and Hindu/ Muslim minority issues in both India and Pakistan as fertile ground for testing con- 
ceptions of community, minority, and democracy, with South Asia's partition seen as the failure of its potential for consociation. But it may not solve the only, or most important, problems with postcolonial states if the cosmopolitan world simply teaches reliance on power-sharing to ameliorate the unresolvable among citizens' differences in cultural and religious value-orientations. Here we learn about sustained, perduring structures of violence from the other trauma of South Asia's decolonization. In the interests of time and to insure that we move from whole to part, our story starts long after it actually began, and we barely touch on its roots, above all looking over the shoulders of the famous progressive anticolonialist, Jawaharlal Nehru. Thus we will start with the real impact of the famous 1955 African-Asian Conference at Bandung on Highland Asia to clarify why, in a range of styles, the substance of politics in Highland Asia from Afghanistan to Burma has been endless military rule, usually with explicit impunity for military violence against civilians (from China's endless imprisonments and the American drones and their 'collateral damage,' among the most imperious, to India's staged 'encounter killings' of Northeast dissidents, among the most hypocritical).

This account of the Bandung Conference, examining Bandung from the points of view of the one hundred million people who live in Highland Asia, will not follow the typical modes for writing the Bandung Conference story. ${ }^{7}$ Yes, at Bandung, Asian leaders took control of Asia's political destiny. But in the same moment, one hundred million people lost their last best chance at a right to self-determine via independent nation and state. There were no representatives of Tibet invited to the table at Bandung. And Tibet is merely the most charismatic of many highland groups whose diplomatic and military claims on nationhood and statehood were neglected. Consider for example the Karen on the Thai Burma border, seven million, in the 1940s armed, trained and organized by the British Special Forces to fight the Japanese, then abandoned when the keys to the one-time kingdom were handed by the British, in 1948, to leaders of the Burman lowlanders, most of whom had allied with the Japanese. The Naga, the Wa, and myriad other highlander groups would have similar stories to tell: what some Pathan thought, and more important, did about the partition of India and Pakistan started the troubles that have never ended for semi-partitioned Kashmir, without any recognition of a Kashmiri nation, let alone a Pathan one. ${ }^{8}$ Jean Michaud (2006), Willem van Schendel (2005) and James Scott (2009) have led scholarly reconsideration of these highlands (uplands, massif) as a geographical,

\footnotetext{
7 On the model of Henry Louis Gates's (1991) critique of "Critical Fanonism," let us resist "Critical Bandungism." Gates argued that a generation of postcolonial theorists were over-reading Frantz Fanon and misrecognizing his French roots, because they wanted a social theorist to proclaim authentic voice of the colonized, the third world, the global south, the wretched of the earth. Similarly, not only in the non-aligned movement itself but in global nostalgia for its quest for a third way outside of the soviet communism and western capitalism, there was vast hope to see only some things, and not others, planned and produced out of the diplomatic discussions at the Africa-Asia Conference in Bandung. ${ }^{8}$ On the Wa, see Fiskesjö (2010). On Kashmir and on Northeast India, a good place to start is Ramchandra Guha (2007); for Northeast India see also Baruah (2005).
} 
historical, and political entity - here termed not 'Zomia' but the more user-friendly Highland Asia, or Asian Highlands. Leaving aside geographic determinism, leaving aside any romantic notion of the region as culturally anarchist, and above all, leaving aside the British allochronic cultural fantasy that the region was tribal in the sense of primitive, we reconsider the fate of the Highlands at Bandung, in effect at the moment where James Scott's more romantic and geographic story leaves off, after World War II and ensuing events have engaged what Scott (2009) calls "distance demolishing technologies" to make Highland Asia a part of the rest of the world. What happened to the Highlands at the Bandung Conference?

In short, Jawaharlal Nehru and Zhou En Lai made a very large deal, a deal all about borders, metaphorical and literal. The deal was already made in outline the year before, in conversations between them in Delhi in 1954. Each made major concessions. Zhou, against Mao's advice, sought a diplomatic foundation for 'peaceful coexistence' with his neighboring states. Arriving at Bandung with the experience of tens of millions of war deaths behind him, from China's World War II through Revolution and warfare in Korea and Vietnam, Zhou led an exhausted and depleted warfare state. He was willing to sign on to the United Nations rules and definitions for legitimate and illegitimate warfare, and even rules against political intervention into other countries. ${ }^{9}$ Nehru, contrapositively, was willing to act outside of the UN's mantle, despite his achievements there, and challenged the West's Cold War by planning Asian history in Asia, for Asia. ${ }^{10}$ Reflecting careful compromises and strong political will, the final Bandung communiqué was about other things too. It famously condemned colonialism in all its manifestations. ${ }^{11}$ In its ten points, built from seven drafted by Zhou, Nehru, and the Burmans, it added as point one an endorsement of the UN charter on human rights, and in its last two points called for economic and social cooperation among its signatories. From this the story of birth of a non-

\footnotetext{
${ }^{9}$ Mao, like Che Guevarra a decade later and elsewhere, was highly skeptical that the political lackeys of global capital (a category in which Mao included Nehru) could be trusted to stay peaceful and abide while a socialist revolution consolidated. Four years later, when the Dalai Lama fled from China to India, Mao was privately critical of Zhou and publicly of Nehru, and his unforgiving diplomatic criticism played a major role in the increasingly hostile exchanges between India and China that led three years later to the Sino-Indian border war. This war, a classically Maoist exercise in demonstrating that power flowed from the barrel of a gun, enabled China to declare exactly where the borders would be and left Nehru more bitter than any political event in his life (Ramachandra Guha 1999, 2007).

${ }^{10}$ See also Mazower (2009) on Nehru's 1946 UN triumph versus Smuts and global racism, and Ramchandra Guha (2007) on the UN's deliberate reconfiguration of Kashmir politics in a mode that stymied Nehru's effort to mobilize the UN against Pakistan. In 1955 the UN still refused to recognize the legitimacy of Mao and Zhou's China, but Zhou was willing even to abandon the phrase "peaceful coexistence," and redeploy rhetoric from the UN charter (Wright 1956), to enable in substance Nehru and Zhou's deal to settle borders and sovereignties and end legitimate war in Asia - which was to say, between states in Asia, not between each state and those resisting among its claimed citizenry.

${ }^{11}$ Zhou ignored the anti-Soviet debate leading to this phrasing and insisted it referred only to European empires. "There cannot possibly be any other interpretation," he told the National People's Congress in May 1955 (Kahin 1956: 62).
} 
aligned movement has real roots. But the remaining seven points are an expansion and consolidation of the five-point deal between Nehru and Zhou, which was also accepted by Burma's rulers before the Bandung conference began: a deal for recognition, non-intervention, and respect for settled borders of three new nation-states, India, China, and Burma. The observers of Bandung from the Nanyang (overseas Chinese) world trusted Nehru little and Zhou less, and argued that the non-intervention promise was never seriously embraced by the mainland Chinese state. ${ }^{12}$ But at Bandung this sovereignty question was basic: would Revolutionary China, with its updated doctrines founded on Lenin's united front strategy and permanent revolution, would this China seek to claim via sovereign authority over Southeast Asia's tens of millions of Chinese-heritage residents a right to rework government across Southeast Asia? Zhou, cognizantly, was trading away any sovereign claim of right to sponsor Southeast Asian revolution. And what he was getting in return was not small: it was Tibet. Nehru agreed, first of all in Delhi in 1954, to withdraw the remnants of an originally British claim to suzerainty in Tibet, a small chain of sleepy post-offices with armed guards styled as government outposts. He also agreed, generally, not to interfere in future events there, construed as 'internal' matters for China. In return he got a promise of peace and room for national industrial development policies, all the rage in the mid-twentieth century on all sides of the Cold War. Nehru was trading for peace and prosperity, and he traded away other people's freedom. This did not happen by accident. In 1956 he met the Dalai Lama for the first time, and the Dalai Lama managed to find, in a private garden walk, the occasion to brief Nehru about efforts to organize resistance against the Chinese occupation of Tibet. He implored Nehru for help, much preferred to that of the American CIA. It would not be fair to say, of this meeting, that Nehru did nothing. In fact, he returned with the Dalai Lama, who was there as part of Zhou En Lai's entourage for this diplomatic visit, and continued to negotiate with Zhou.

Any attribution of a particular motive to a Nehruvian action, for example his military occupation of Kashmir, has to reckon with the many levels and types of intellectual tensions that organize his thinking. ${ }^{13}$ Let us outline not his motives but

${ }_{12}$ Here see also Tan and Acharya (2008). The Singaporean and other Southeast Asian skepticism that Mao's state accepted Zhou's commitment to peaceful coexistence had evidence and consequences. In an era informed by Lenin's advice that revolutionary parties form 'united fronts' with bourgeois parties to decolonize, and then betray them, the 1960s were scene of tense suspicion and violently exploded alliances: after the 1962 Sino-Indian border war, while China's left led a succession of cultural revolutions against Zhou's state, Singapore's PAP acceded to the 'Cold Store' of its leftists, arrested before elections, and 1964 became Indonesia's year of living dangerously, in which erstwhile allies turned murderously onto Indonesia's Marxist left, killing a half-million people. And even the good fences of partition could not bring peaceful coexistence to North and South Vietnam.

13 At present I have a book underway that addresses many dimensions of Nehru's complex decisionmaking here. Nehru is a free agent and is no one's Subaltern. To grasp many of his actions we need to consider at least seven dialectical tension points in his thinking. For example, there is his waning, originally intense commitment, to international socialist revolution (in his 1934 history lesson for Indira, he explains who Gandhi is, in Indian history, by calling him "the Lenin of India"). Second, there is his 
his actions, to understand how clear and sustained the line of events was that consolidated the Indian nation-state and undermined sovereignty claims and other political claims at many locations in the highlands.

In Kashmir, on 22 October 1947, diplomat extraordinaire V.P. Menon (Source) tried to complete his exhausting diplomatic brief and arrange the political "accession," as they called it, of one of the last of over 500 so-called "princely states" into union with the nation-state of India. Most had acceded on the promise of favorable terms before India's own independence on 15 August 1947. But Kashmir resisted, the Maharaja long a rival of the Muslim-led Congress Party in his own electoral assembly, until the October "invasion" of Kashmir from its north-west by a large and unprecedentedly well-armed Pathan raiding party. Beyond doubt the new weaponry was courtesy of the new state of Pakistan; whether it was intended for border patrolling rather than the traditional raiding on the lowlands, let alone whether a war of conquest was chartered by the new Muslim state, are matters still murky and doubtful. But once Menon was in the capital on 26 October, the fearful Maharaja was immediately woken to sign a standard treaty of princely accession. While the Pathan raiders surprised the cities by turning back to their homelands, in no small part because their carts were already overladen from the abandoned towns in their path, it was the Indian Army that occupied the famous southern Kashmir valleys. Stanley Tambiah, in his modern classic study of violence, Leveling Crowds (1996), calls it "focalization" and "transvaluation," paired processes, when events are stripped of their contingencies, here for example Sheikh Mohammed Abdullah's leadership of the

Gandhian commitment to satyagraha, swaraj and ahimsa, i.e., insistence on the truth, self-disciplining self-rule, and nonviolence. Third, his anticolonialism, manifest for example in his efforts to negotiate on behalf of the Indian National Congress working committee the meaning of World War II as grounds for Indian participation: where, in September 1939, he and the congress pledged to join any war effort that genuinely supported democracy and freedom against fascism and imperialism (Zaidi 1985: 26), the king pledged of war of right against might (21) and viceroy, a struggle of reason, right, justice and human freedom (and not, independence) against the rule of force (and not, imperialism or colonialism) (21-23). Fourth, there is his statism, his commitment to one big union, which links to his faith in the United Nations as well as his many actions once in office that, for reasons of state, worked to consolidate central power at the expense of regional and foreign interests. Fifth, his anthropology, especially in his appointment of amateur anthropologist Verrier Elwin to a series of executive posts in control of various so-called tribal territories in newly independent India (see also his call for highlanders to sing, dance, and ignore the modern world, Nehru [1952] 2006). Sixth, his complex responses to America. While in prison during World War II, his writing The Discovery of India (Nehru 1946) in the end metamorphosed into a discovery of America, especially after he read Nicholas Spykman's The Geography of the Peace (1944) from which he confronted the theory that the future of the world would be shaped in response to the two waxing "super powers," leading Nehru to the chapter "Realism and Geopolitics, World Conquest or World Association: the U.S.A. and the U.S.S.R." Seventh, and I think in sum, the influence on his vision of H.G. Wells's version of benevolent, scientific, democratic socialism (see, e.g., Wells 1920). In the end it might be his commitment to scientific solutions and his Elwinian, essentially ninteenth-century evolutionary anthropology, as well as big-state geopolitics, that led Nehru to see self-ruling Highlanders as not only dangerous but "absurd," despite his long experience of the politics of condescension. 
Kashmir National Conference, closely allied with India's Congress Party. Focalization reduces complexity to a simple script, as when the complex ethnic and religious lines of Kashmir's many parts, only some of which are Muslim majority and one of which is mostly Tibetan Buddhist and Muslim, become a province with a Muslim majority and a Hindu raja. The politics of 1947 - when Mountbatten undertook personally to forestall Nehru and Jinnah, while Abdullah held out for an election to decide which country to join (which he clearly thought India would win easily), and while the Maharaja negotiated for a 'standstill' agreement in preference to an accession and merger in order to retain his title - all gets simplified to the story of a Hindu maharaja wanting the Hindu nation-state while the Muslim majority allegedly wanted the Muslim nation-state. Simplified and also falsified: that is the extreme in transvaluation, which unlike focalization is the adding of meaning, theme, and even detail to a story to render it intelligible and significant in a larger, more global narrative - here the story of Hindu-Muslim communalism which, by August 1947, was already traumatically saturated by the blood of a million and more dead.

But the transvaluation, and the real tragedy for peace, prosperity and freedom in Kashmir was yet to be locked into place. That happened in early 1948, when Nehru was stunned at the United Nations. Here, again, we need a bit of background. Michael Mazower (2009) has shown, vividly, in his book No Enchanted Palace about the utopian and realist diplomacy surrounding the establishment of the UN, that Nehru shocked the UN establishment with a remarkable victory in 1946. Nehru and the rest of the Indian delegation attacked South Africa for the racism of its emerging apartheid system, as another form of colonialism repugnant to global conscience. Jan Smuts, architect of the UN's original, permissive colonial policy and author of much of its black letter law on non-interference in internal affairs of member states, was correctly confident that he was on the right side of UN policy and procedure. But Nehru won the vote in the General Assembly to find instituted racism a matter of global concern and South Africa beyond the bounds of civility. That's where Mazower's story ends - as he sees it, the first glimmer of decolonized dominance in the General Assembly votes - and our story begins, the payback. In 1948, in short, Nehru was shocked when the Security Council accepted Pakistan's definition of the Kashmir issues, a malformed and incomplete border, rather than the case he himself had brought, the need to reverse an invasion. Nehru had hoped to use the UN prestige and escort to push Indian troops through the Pathan north without violence. Instead, he got a 'line of control' across the center of Kashmir at the limits of his own military occupation of the Southern and Eastern districts. This transvaluation had Cold War thematics. Both the British and Americans wanted Pakistan as an ally against the Soviets. But the payback dimension should not be discounted, as the Security Council takes back the UN from Nehru's nascent global south. And Kashmir became the irreconcilable territory, by UN deliberate choice. Pakistan, to increase pressure for a unification into Pakistan, built its ISI, Directorate of Inter-Services Intelligence, notorious engine of jihadist insurrectionists, to sponsor the sorts of movements in southern Kashmir that would pressure for accession into Pakistan. 
Democratically inclined Sheik Abdullah was the odd man out. And even a generation later, in the wake of 9/11, ISI would still be plotting how to manipulate presences and absences of global jihad in order to gain the rest of Kashmir, oblivious to the impact of the jihadist politics they fomented elsewhere, notably Afghanistan.

Thus the prospects for a Pathanistan, in northern Kashmir and Pakistan, were never part of any serious global diplomatic discussion. While Menon signed up over 500 princely states by getting rajas and nawabs to sign accession treaties, including Manipur, an Ahom satellite state in a major rice valley in Northeast India, no one undertook similar diplomacy with the so-called 'Hill Tribes,' even though their populations were, in many cases, in the multiple millions. Neither Mountbatten, Jinnah, Nehru, nor anyone from the Congress or Muslim league ever campaigned for accession arrangements among the Pathans or, in Northeast India, with the Nagas, Kuki, or any other upland group. The English speaking, American Baptist missionary-educated Naga elite was campaigning throughout the mid and late 1940s for a Nagalim, an independent Naga nation, more fiercely after Nehru's government banned the American missionaries. The leading Naga newspaper called for it with an elegant dialogic reworking of Lincoln at Gettysburg: the Nagas, at least one faction claimed, wanted government "of the Nagas, for the Nagas, by the Nagas" (Guha 2007: 268). Congress responded by appointing ex-missionary, ex-Gandhian amateur anthropologist Verrier Elwin to manage the tribal territories. When Nehru finally visited - not the Naga hills but the adjacent, plantation-rich and six-times more populous Assam valley, on a campaign swing in 1951 - Naga leader Angami Zapu Phizo was able to present the case for Nagalim directly. Nehru avowed no knowledge of the famous story that Gandhi, meeting with Phizo shortly before his death, had advised the Naga to stay in India but affirmed their right to depart, promising to stand with them against the Indian Army if necessary. And Nehru did not say yes or no to the Naga demand. He said, "absurd." Anthropologically inflected? Nehru suggested that the Naga should be protected from the modern world, that they were "Above all ... a people who sing and dance and try to enjoy life; not people who sit in stock exchanges, shout at one another and think themselves civilized" (Nehru 1952: 3). He blamed foreign missionaries, whom he thought unsympathetic to the Indian National Congress, for independence movements against India, and hoped, implicitly, that the hill tribes would abandon their Christianity. Focalization and transvaluation in the locality: since the 1950s, Christian conversion has galloped in Nagaland, and $71 \%$ of Naga adults are now registered members of the Baptist Church, which compares to Mississippi, the highest similar percentage among American states, at $51 \%$. But finally, in justifying his hold on the hills, Nehru the statesman cited, above all, a heterogeneity of "security concerns," in one stew the problem of his Chinese and Burman borders, and also the prospect that if he acceded to independence for the Nagas, his troubles in Kashmir and even in Tamil Nadu and elsewhere would explode. Nehru was perfectly ready to override the political will of highlanders, especially when engagement with the central government would obviously be good for them - an astonishing social theory from the world leader of anticolonialism. 
Finally, the clearest case of this trend is Burma, and Nehru's largely underestimated role in its history of civil war. Even the estimable historian Ramachandra Guha (2007) with his exemplary attention to Kashmir and Northeast India misses this key piece of the puzzle that is Nehru's highland policies and practices. In February 1949, the Burma highlanders came the closest to claiming sovereignty over a large state of any highland army in the postwar period - and Nehru deliberately sabotaged them. In Burma, the violence of World War II had never really ended. The Karen, the Kachin, the Shan and many other highland groups had been courted by the British and provoked to campaign against Japan's Coprosperity Sphere, which ruled lowland Burma for most of the war but never sought to penetrate the highlands except for its failed efforts to shut down the famous Burma Road. The British and even the Americans had good reason for a wartime highlands policy: the Japanese had cut off China's armies from all seaports, and 'flying the hump' was not practical as the sole means of provisioning China's army. The Allies not only managed to reopen the road connecting Mandalay to Kunming in Yunnan, but with remarkable engineering efforts they managed to build a new road from Assam through the mountains, the Ledo Road or Stillwell Road. This road connected the railhead in India with cities in reach of Chiang Kai-shek's army.

Ordinarily, military victors would remember who were their friends, and who their enemies, but other currents ran deeper in decolonizing Asia. Under pressure from both the Indian National Congress and their own wrecked finances to decolonize as quickly as possible, in 1948 the British gave the keys to Burma to the Burman government centered in Rangoon. The hills erupted in rebellion, and were vastly better prepared for actual fighting, especially Smith Dun's Karen National Union army with a long memory of continuous bloody skirmishing with Japanese and Burmans. By February, 1949, ten thousand Karen National Union soldiers surrounded Rangoon, and the nascent Burman state came to be called the 'Seven Mile Government.' The Burman Prime Minister U Nu appealed to Nehru for support and aid, and got it. U Nu's career is long and interesting. Foreign Minister in the Japanese sponsored occupation government, ally of Aung San and his successor when Aung San was assassinated in 1947, U Nu is the same Burman leader who helped Nehru and Zhou sponsor the Bandung Conference and was the third signatory to the deal between Nehru and Zhou securing the borders before that conference began. In 1962 he would lose power to Ne Win's military coup and in 1988 would fail to regain it for himself and Aung San's elected daughter Aung San Suu Kyi. But in February $1948 \mathrm{U} \mathrm{Nu}$ was desperate. And Nehru saved him. The means were subtle. Nehru brokered the ceasefire and offered to sponsor the negotiations between the sides. He then called in the British Commonwealth to mediate, for the first and only time in his career, with predictable results: gathering in Delhi, Commonwealth diplomats devised a power-sharing peace plan and declared publicly their willingness to lead the peace talks and orchestrate a plan for new government in Burma. $\mathrm{U} \mathrm{Nu}$ and his leading general the future dictator Ne Win fiercely declined. By then they could afford to. Nehru had quietly but decisively rearmed and equipped the Burman 
national army, requiring that the Burmans keep the military support entirely secret (Bayly and Harper 2007: 464-67). The Karen National Army was pushed back into its hills, where it still holds territory today, though few states recognize its claim to be the independent nation-state Kawthulee.

We need not conclude that highland nation-states are the Shangri-La lost to history by failures to recognize true nations. The history of Nepal is sufficient to suggest problems with that interpretation. (And Veblen, as we shall see, would point us in the opposite direction, toward a terrain of state military investments and their interests that precede, bound, inform, enable and delimit every venture in citizenly sentiment.) The highlands social history and political geography - even its historic economics of highland meat traded for lowland rice, its political economy of trading and raiding, hiding and seeking - create complexes that ill fit the nation-state model. These highlands gained their social contours while functioning for a millennium on the periphery of empires (and including two perduring highland empires: the Ahom galactic polity emanating from Assam until the 1820s, and the Lamaist Tibetan Buddhist theocracy, finally destroyed, not coincidentally, in 1956, the year after the Bandung Conference; see also McGranahan 2010: 67ff). More important to $\mathrm{us}$ is the reconfiguration of social relations, and social regard, in the highlands worked by the British Empire, and its consequences. In short, and to speak broadly, in British eyes the lowlanders became Orientals. The vast populations of lowlanders were seen, depicted and dealt with by way of all of the attendant stereotypic characteristics: as Orientals, imagined morally suspect, deceitful, and of uncertain masculinity but vast intelligence and resourcefulness. And the highlanders were generally seen as tribal: hill tribes, imagined to be primitive, emotional more than rational, fearful of the outside world, in need of moral guidance and protection, childlike, and hyper masculine. It never surprised the British when highlanders were adept at skirmishing warfare, from the Pathans to the Karen, though they ascribed it to race rather than history. ${ }^{14}$

The general point, here, is not about military intervention as a distortion of normal development of nation-states, but rather the opposite: that state power has, for a very long time, constituted and distributed the opportunities for states, and nations, to develop - with violence where necessary. Review of this reiterated history of coercive, military rejection of claims to sovereignty deemed 'tribal' makes the question of joining or resisting a national formation - the question, belonging to what? - less naïve. Ali Sastroamidjojo's Conference-orienting question, "Where do we stand now, we the people of Asia, in this world of ours today?" better situates the matter, as one recognizes the opportunity for nation-building, and nation-joining, as a function of larger forces. And if, indeed, military conditions of possibility are the rule, and not

\footnotetext{
${ }_{14}$ The fascinating story of the British Army's own commitment to their fantasy, and turn to reliance on Gurkhas, and the attendant scramble in Nepal for increasing numbers of families, clans and villages to stake claims to Gurkha identity, has been well documented elsewhere (Des Chene 1991). A similar history makes ethnic Fijians valuable in the postcolonial British army (see May 2014).
} 
the exception, for national prospects, we should neither neglect the colonial roots of most postcolonial situations, nor neglect the postcolonial appropriation - precisely, for Asia, at the Bandung Conference - of this precedent power. The British, fearful and respectful of highland warfare, but not highland politics, and no more respectful and equally fearful of lowland political aspirations, carved boundaries and built political and civil institutions according to their own anticipations and expediencies. Their empire set baseline contours and political preconditions that, at the Bandung Conference, new Asian powers deliberately locked into an order of allowed nation-states for Asia. Whether Nehru too was a racist is not the first question. $\mathrm{He}$ inherited an Assam already constituted, in British colonial capitalism, with an inner line sharply separating the populous lowland plantation zone from the so-called tribal highlands. While British courts carefully managed the investments and labor contracts for tens of millions of workers on myriad lowland Assam plantations, only Christian missionaries regularly entered the highlands, which knew little law of any kind, even Ahom. Thus, when Nehru called Phizo "absurd," and couldn't imagine a Pathanistan, nor allow a Burma ruled by highland groups, we need to track his own deliberate critique of colonial and postcolonial theories and realities. Nehru was highly influenced by Verrier Elwin's romantic ethnography. Nehru enabled Elwin to impose a protectionist allochronic regime that led inexorably to fifty years of bloody counterinsurgency conflict in Northeast India. But this 'anthropology,' and Nehru's own vision of progress and primitivism, owed more to nineteenth century anthropology than to the twentieth century Boasian cultural relativism, with its nostalgia for savage, natural men. Nehru's source for this imagery was, I think, the same as his source for unalloyed, ultimate confidence in science, industry, and state-led benevolent planning as the foundation for all human progress: the British social democratic intellectual leader, H.G. Wells.

Most pertinent for us, why was Fiji so different? Let's reconsider Fiji's place within a British Empire becoming Commonwealth, to grasp the distinctive politics of its tribes in a world of nation-building.

\section{Tribals and Orientals in British Imperial Fiji: From Gordon's Vision to a Political Army State, and beyond It}

One reason why the Japanese military swept through Malaysia, Singapore and the rest of British Southeast Asia was because, when it came to military affairs and techniques, the Japanese were unhesitant and state of the art. A British imperial army of 80,000 fell almost immediately to a Japanese invasion force of 20,000, because most of that British defense force was sepoys from India, whom the British refused to arm with modern weaponry or train in advanced tactics. The British rarely liked the idea of armed 'Orientals,' in Fiji no more than in Asia. The very last thing the British wanted, in Fiji, was Indo-Fijians seeking to express a military potential. Ironically, the recruits for Fiji's plantations, especially the north Indian recruits, came 
from precisely the towns and cities that were the cachement, for centuries before, of the military labor market (Kolff 1990). Far from the image of eternal peasants uprooted from soil and oriental tradition by the lies of recruitment, Fiji's South Asian plantation laborers came from towns and villages that for centuries had seen foreign service in caravan armies make boys into men, i.e., men with financial stakes and personal alliances capable of supporting independent households and thus ready for marriage. The British Raj disarmed the caravans, and put the military labor market out of business, creating the massive dislocation and underemployment that made this recruiting belt ripe for the lies of plantation recruitment, lies especially about hardship, distance, and types of work required. And in Fiji the state deliberately sustained its hostile distance from the lives of the girmitiyas, "a working population and nothing more" in the words of the colony's second Governor (Kelly and Kaplan 2001b: 149).

But this notwithstanding, Fiji's history is in other ways decisively different, specifically in its Pacific Romance that Martha Kaplan (1995), Brij Lal (2010, 2011, 2012) and others have delineated in their scholarship on colonial Fiji and its contours. The very history of resistance to recognition of the sovereignty of armed, multi-million strong highland societies should signal the extraordinariness of Gordon's legal and social policies for Fiji, above all his configuration of forms of aristocracy and even sovereignty for the ethnic Fijian chiefs. Fiji, too, has in its land policies an echo of the inner line, but almost in reverse: it is tribal lands that are protected, bounded, catalogued and reserved. Gordon's land settlement plans included a very important nuance: the ethnic Fijian land reserve policy did not stop him from cutting out and assigning to the Colonial Sugar Refining (CSR) company a vast amount of Fiji's best agricultural land, and in fact his promise to leave the rest in the Fijian reserves was crucial to his ability to entice CSR, Australia's leading sugar refiner, to invest in Fiji. The plan all along was simultaneously to secure Fijian chiefly right and CSR monopsony, a plan for which Gordon credited J.W.B. Money's critique of the causes of the Mutiny in India, and the need to keep races in their places (see also Kelly 2004).

Fiji too has its official deployments of ethnological theory: rather than Verrier Elwin's love of primitivism, it had the more sober and professional Rusiate Nayacakalou, student of Raymond Firth. Nayacakalou channeled by way of Firth the evolutionary vision of Henry Maine as he advised the Great Council of Chiefs about Native Administration and managed the Native Lands Trust Board through Fiji's decolonization to the end of his life in 1972. Nayacakalou explained Fiji's political dilemmas as ethnic Fijian problems with the culture of capitalist individualism and political democracy. Drawing on Maine's famous status-to-contract vision of social evolution, he influentially declared the ethnic Fijians people of "status" and not "contract."

Critics of British policy toward ethnic Fijians in Fiji deployed as many easy evolutionary assumptions as did the champions of the policy: ethnic Fijians were either kept backward, frozen away from progress, or else protected and shepherded more slowly. Leaving aside evolutionary tropes and allochronic judgments, something very 
different took shape in the circuits of affection animating many British institutions in Fiji, notably the army and the Great Council of Chiefs. As the army in Fiji metamorphosed from white ('European') officers and enlisted men, to white leaders over ethnic Fijian men, to ethnic Fijian officers and men, to ethnic Fijians joining the British as well as Fijian armies, and favoring the former (see also May 2014), the army in Fiji increasingly became a nexus of ethnic Fijian sovereign expression. When its special forces led coups, its mana thus expressed made it the classic political army, vehicle of national self-determining by taking over the state. With no democratic give and take, Fiji then was neither a nation nor a state legitimated by contractual transaction among citizens. Nor was it a pre-emptive state, like Nehru's destroying Naga claims to sovereignty in order to protect them, a state pre-emptively protecting. Eventually, yes, the political army renewing Fijian sovereignty and ownership of Fiji would give way, in the latest, strangest coup, as the military destroyed even the Great Council of Chiefs, and ended the districting that privileged Fijian votes, in what its leader told the UN, in 2007, was the "coup to end all coups" (Fraenkel and Firth 2009: 455, 458n13). But until 2006, Fijian sovereignty, ownership, and political will asserted itself with extraordinary lack of limit, without balance of any alienation, without recognition of other right. Whereas the Wilsonian liberal nationstate paradigm relied on vast contractual rules, abjuration of all right of violence, and remade the nation from blood into law via the new being expressed by state, this Fijian nation was not alienated from kinship (especially, in Sahlins' sense of shared substance), not made in public, not even dependent on any larger justice than its own. The Indo-Fijians were not then invited to join it, could not become the taukei or owners of the land, nation, or state. And remarkably, despite the limited actions expected from them, they found powerful means of their own to resist, withdraw, object, and peacefully not cooperate.

"Belonging to what?" then, metamorphoses into "belonging or what?" After so many have asked what Fiji's ethnic landscape meant for prospects of postcolonial citizenship, let us ask instead about the implications, and options, for diasporic exIndians in the wake of Fiji's unique deployments of colonial and postcolonial state power, about the effects of Fiji's unique relations between 'tribe' and 'state,' and about the metamorphosing consequences of the vectors of sympathy ensconced in institutions of violence. We find in Fiji, from the first Governor to the last, from the already elegiac Sir Arthur Gordon of the 1870s to the unpleasantly sardonic Tim Hardy, "The Reluctant Imperialist" of the 1960s (see also Kaplan's comments), we find ensconced in the 1970 independence Constitution, a colonial and then postcolonial state remarkably different in the orientation of its implements of violence toward the relationship of state and tribe. Publishing in 2009, thus with the condescension, also, of hindsight, Hardy remembers shuttering most of the Special Branch offices uselessly probing for revolutionaries among the Indians and labor unions, and predicting that "the only serious threat facing Fiji for as long as it was possible to foresee was that, if provoked by the formation of a government perceived by Fijians to be dominated by non-indigenes, the Fiji military might stage a coup d'etat" 
(2009: 338). But Hardy's British Empire was more concerned with whether the ethnic Fijians would accept independence, than with the limits of their commitment to democracy. In fact, he recalls a "blimpish junta" of British colonials, reveling in Fiji's imperial backwater.

That blimpish junta continually warned Fiji's Great Council of Chiefs that without the crown's protection the weak, 'backward' Fijians would fall under the domination of Indian 'immigrants,' resulting in the liquidation of the system of chieftainships and the end of Fijian culture. By nature conservative in the first place, the chiefs weren't hard to convince. Indeed, the blimps' propaganda terrified them. (ibid.: 353)

Almost no one in decolonizing Fiji protested the impropriety of an army built up entirely of ethnic Fijians - not because the asymmetry was ignored, but because it was a comfort for the chiefs.

Hardy served in British and then Malaysian Sarawak before Fiji, through much of the 1960s, through the tail-end of counter-insurgency against Chinese communists, integration of Sarawak into decolonized Malaysia, the failure of Indonesian pan-Malaysian political plans, even Indonesia's year of living dangerously. He assiduously tracked actual, and increasingly pathetic, Maoist rebels in Sarawak, especially after the slaughter in Indonesia, and in 1965 gathered evidence of mainland China's refusal to send arms or funds to them.

All were happy to hear of 'O's plight and of China's refusal to help but some of the heavies in KL, London, Labuan, Washington and Kuching were none too pleased to be shown proof that one of their articles of faith - that Mao handed guns to every third-world troublemaker who asked for them - was, simply, untrue. They had exploited the line that Mao was behind every gun pointed at Western interests in Asia to support their continuous - and successful - clamour for more weaponry for themselves. They didn't change their tune. (ibid.:300)

Hardy knew how far colonial state antipathy for both Chinese and Malay political agents could go, especially antipathy for Chinese communists. Serving in postcolonial Malaysia, "a foreigner in the service of a sovereign Asian nation ... I had to keep my opinions to myself" when a wrongheaded colonial identification of a Chinese village as communist led to a perimeter fence and curfew, a policy "vindictive, unjust, small-minded, politically daft and materially wasteful" (ibid.: 313). He was disgusted, more than surprised, he says, when "the Indonesian army turned its back on Malaysia and turned its weapons on its own people" (ibid.: 314).

Fiji, then, appalled Hardy differently, not especially for its state violence, since it was clearly more peaceful, but for the more complete absence of justification for it. "They spoke darkly of 'subversives' like the local Indian political leader, A.D. Patel" 
(ibid.: 321), but there were no actual subversives. Like New York Times political reporter Henry Kamm (1988) in Fiji a generation later, observing after Fiji's second 1987 coup the many military checkpoints, and realizing that the military were deploying a technique learned in Middle Eastern peacekeeping, against a population bereft of insurgents to catch, Hardy quickly realized in decolonizing Fiji that the state's affections and contempt were generating both ritual pomp and widespread fear. Hardy did what he could to dismantle Special Branch, he says, and left, this time, at independence.

The distribution of power is remarkably different, clearly, in the vast India shaped by the Indian National Congress, and the comparatively tiny islands of Fiji ruled through several elections after 1970 by the increasingly chiefly Alliance Party. Consideration of sovereignty frustrations among Asian highland groups more than ten times more populous than ethnic Fijians can remind us of the unique benefits, not least in recognition of the political rights of ethnic Fijians, that Gordon's original legal system provided the islands. But, this comparison suggests, Fiji's problems stem from more than the failure of its colonial and then postcolonial governments to grant, in similar full measure, recognition of citizen rights and full participation in sovereign activities for the rest of the population of its new republics. Even the idea of coup culture does not fully fathom or locate the problematic principle in its roots, which is the willingness to deploy military force on missions of culturalist counterinsurgency. Sanjib Baruah, in his brilliant monograph on Northeast India's politics, Durable Disorder, quotes Mrinal Miri's "admonition that the idea of a nation having a 'policy' towards part of itself is odd" (Baruah 2005: xvii). Independent Fiji inherited not just a split population, but a long colonial history of very different kinds of policies towards parts of itself, ensconced deeply in its extant social institutions. While the unbalanced social roots and sympathies of the almost entirely ethnic Fijian army made the first four coups and their ethnic vectors clearly legible as interest group politics, we should not be distracted thereby from the fundamental strangeness of the deployment of military force on a mission of cultural protection and provision. In its latest coup, the military clearly seeks to use its tools politically against all claimants of right: it now has policy for, and after all against, everyone's political aspirations.

\section{Shanti and Mana, Grace in Exile and Redemption from Alienation: Belonging to What? Belonging or What?}

"Man needs a master," Immanuel Kant famously concluded in thesis six of his critique of all philosophies of history (Kant [1784] 1991). The end of enlightenment required public control to establish the peace necessary for advance of private reason. Kant here accepted Jean-Jacques Rousseau's ([1762] 1968) commitment to the common will as condition of possibility for private reason, but not John Locke's ([1689] 1988) more sanguine location of natural laws and interests behind the necessary 
violence of the state. Kant's student and trenchant critic Johann Gottfried Herder placed Kant's certitude, correctly, in the "Averroan" tradition, influenced not merely by Hobbes ([1651] 1982) but by the whole discussion of human nature renewed from Aristotelean roots by Ibn Rushd ([1178] 2017), Ibn Khaldun ([1379] 1989), and others on the southern shore of the Mediterranean. It was Herder, constituting a strong argument for constitution of society by human culture, not by political states, who declared that "man needs a master" was a pernicious and erroneous doctrine. ${ }^{15}$ A strong cultural approach (from Herder to Durkheim to Sahlins) locates the fundamental dynamics of society in cultural wholes precedent to and inclusive of the realms and reasons of state.

A very different critique of Hobbes begins with Montesquieu. Herder's simple reversal, that "man needs no master," rendered states, especially strong states like Rome and all future conquest empires simply evil. But Montesquieu worked a sea change, much like that wrought onto Sigmund Freud by Marcel Mauss (1973). It is thanks to society that an unconscious is possible, Mauss and his heir Michel Foucault ([1976] 1978) have shown, not thanks to unconscious needs that society was constituted. Similarly, Montesquieu ([1748] 1989) showed, war begins with states and their specific means and ends. States necessitate war, Montesquieu argued, far from the Hobbesian vision of a natural war of all against all as the thing necessitating states. Humans, then, do not so much need a master as inhabit a different world when they have one. Perhaps the most trenchant, and certainly the fiercest, critic of Kant in this light is Thorstein Veblen ([1917] 1998), present at the creation of the American century, and mordantly observing its roll-out. Precisely as Woodrow Wilson at Versailles began to articulate what has eventually become known as the 'end of history' doctrine - national sovereignty as the only legitimate form of sovereignty Veblen observed realities at odds with the mandates of theory: states coming before nations. Where Wilson depicted self-determining nations expressing their political will via states of their own, Veblen observed states ascribing duties before awarding rights. States grant citizenship and other forms of representation sometimes for some, but tax any and all in blood and treasure, Veblen argued, according to the needs not of nation but of state. Anticipating the new American problematic of 'nation-building' not as global challenge but as global fraud, Veblen saw the deepest problem in all doctrines of political necessity, dialectical and otherwise, lumping Marx and Wilson into the Kantian basket as grand teleologists. Veblen saw a simpler world, not one composed of irreducible wholes with internal dialectics, but merely one of situations that evolve; Veblen resituated the state from a Kantian to a Darwinian universe. Thereby, Veblen also resituated citizenship, rights, and duties into problems inevitably to be negotiated with extant leviathans. Veblen's point of view moves dilemmas of belonging from special case to general question: how do any and all citizens seek peace effectively?

15 "The proposition ought to be reversed: 'The man who needs a master is a mere animal; as soon as he becomes a man, a master is no longer necessary for him.'” Herder ([1800] 1966: 447). 
Observing trends globally, let us list many unintended outcomes of the UN era's global distribution of self-determination in reality. New forms of elite diasporic migration, a kind of self-determination by other means, join with many other unexpected global developments, from the rise of NGOs to many new kinds of low intensity and asymmetric warfare, peacekeeping interventions, and political armies of several kinds - all this despite the American premise that it would be democracy, and not the army, that in the first instance connected the nation to the state, and, as in Fiji, vice versa. To understand the contemporary geography of anger, it is useful to grasp the problems, even the bad faith, in the Wilsonian vision of self-determination as a global economic solution: everyone to set by their actions the terms of their own fate. Self-determination comes originally from John Locke's ([1689] 1988) Protestantism of free will, versus Calvinist predestination in which God decides who finds heaven or hell in their future. Only in the hands of Woodrow Wilson at Versailles did this Christian otherworldly moral doctrine become a vision of how to arrange, or at least imagine, this-worldly fates, and in fact, this-worldly fates not of individuals but of collectives, nations with their own states. The idea made decolonization imaginable, with limited liability to ex-colonizers. It reconfigured as aid and gift all assistance to those whose economic interdependence and even simple economic dependence could henceforth be occluded. Separate but equal, as the Americans once would say approvingly.

But while the American civil rights movement reconsidered the logic of separate but equal at home in the United States, and 'super power' Cold War transvaluations disrupted efforts at peaceful coexistence between nations and states more globally, new kinds of diaspora, after decolonization, have become the exceptions that disproved the rule. Their dilemmas of belonging are not moments of failure in the order of nations and states. They are the actual reality at the limits of all citizenship, in a world where states precede and delimit the structures of opportunity. Precisely where neither self-control nor peace can be taken for granted, such dilemmas are resolvable only by the profoundest value commitments.

As in Fiji: late colonial Fiji's chiefly leadership was famously ambivalent about independence, not surprising given the grounding of their power in the valorization of cultural difference and the protections and supports of Empire. Ironically, the more Fiji's coups restored privilege, and the more the mana of chiefs usurped civil order, the more the resulting instability again suggested threats to settled order and the need for more secure protections. Most recently, for Fijis latest and strangest coup, New Caledonia's Noumea Accords have unfortunately provided an all too attractive military model. In New Caledonia (to finish, here, with a military governmentality closer in many ways to contemporary Fiji's) the perduring French colonial state enforces a policy against open politics in its civil space. The Noumea Accords create highly temporary peace between indigenes and settlers by banning elections, in order to break cycles of election tension and conflict. The states in both New Caledonia and Fiji hope that demography and new economies will transform political interests. But in fact, as in the closely kindred counterinsurgency occupations in Highland 
Asia and elsewhere, such military suppression of democratic political activity almost inevitably generates, instead, a new and growing geography of anger. Thus Fiji has moved from the problem of Indian belonging, to the problem of anyone bearing actual rights. In quest for road maps, the military has traded the cartoons of the colonial blimpish junta for blank pieces of paper.

Compared to Burma, Tibet, Afghanistan, Pakistan, Kashmir, most of Northeast India, and most of the rest of the Asian Highlands, Fiji today looks peaceful, prosperous, and even in some ways free. In Fiji, the demographics might well bring a happy ending if and when ethnic Fijians can accept democracy after all, and there is nothing like absence to make the heart grow fonder. Indo-Fijians have sustained their commitment to shanti-morally-uplifting peacefulness - and are already among the world's leaders in recognizing the emergent reality of global citizenship. Ethnic Fijians operate socially and politically by way of a volatile mixture of evangelism, nostalgia, rent-seeking, and cultural pride, interrupting the market models of self-interest more congruent with legitimacy for neo-liberal democracy, such as it is. That is why, for a long time now, the biggest conflicts in Fiji have not been between Indo-Fijians and ethnic Fijians but among ethnic Fijians, a trend that will continue.

This conclusion does not proffer for Fiji a general political solution, but instead observes the positive content that this postcolonial political history has rendered for Fiji's citizens and cultures, on many sides. Many ethnic Fijians, especially those not privileged in the capitalist economy, still treasure their heritage of self-definition with a tribal counter-concept, in a quest for life without alienation. This self-determination is of and for a culturally collective self, and it is as often committed to loloma, kindly love, as it is to the aggressions of mana. Indo-Fijians, meanwhile, still face the cardinal Maussian problematic of how to give without subordinating self to other, and feel existential risk regardless of whether they are staying or going. Continuing peace in Fiji depends still on whether those two goals can be reconciled, mana and shanti, regardless of how long the military keep all sides frozen via antipolitical strategies. Fiji's best hope is that anger against its antipolitical state will simultaneously be firm enough and yet moderate enough to provide the common ground on which not so much one nation as an acceptable interdependence can be realized. In fact, Fiji is ironically well positioned to pierce in practice the illusions of independence and purely self-determination, and in a shared cultural field of recognized and reconciled differences, to move toward a common future without the need, in the end, to build one nation or even to want one. 


\section{References}

Ahmed, Akbar. 2013. The Thistle and the Drone: How America's War on Terror Became a Global War on Tribal Islam. Washington: Brookings Institution Press.

Appadurai, Arjun. 2006. Fear of Small Numbers: An Essay on the Geography of Anger. Durham: Duke University Press.

Baruah, Sanjib. 2005. Durable Disorder: Understanding the Politics of Northeast India. New Delhi: Oxford University Press.

Bayly, Christopher, and Tim Harper. 2007. Forgotten Wars: Freedom and Revolution in Southeast Asia. Cambridge: Belknap Press of Harvard University Press.

Benedict, Ruth. 1946. The Chrysanthemum and the Sword: Patterns of Japanese Culture. Boston: Houghton Mifflin.

Bharati, Agehananda. 1972. The Asians in East Africa: Jayhind and Uhuru. Chicago: Nelson-Hall.

Das, Veena. 1995. Critical Events: An Anthropological Perspective on Contemporary India. Delhi: Oxford University Press.

Des Chene, Mary K. 1991. "Relics of Empire: A Cultural History of the Gurkhas." $\mathrm{PhD}$ dissertation, Stanford University, Department of Anthropology.

Firth, Stewart. 2000. "Decolonization." In Remembrance of Pacific Pasts: An Invitation to Remake History, edited by Robert Borofsky, 314-32. Honolulu: University of Hawai'i Press.

Fiskesjö, Magnus. 2010. "Mining, History, and the Anti-State Wa: The Politics of Autonomy Between Burma and China." Journal of Global History 5 (2): 241-64. doi:10.1017/S1740022810000070.

Foucault, Michel. (1976) 1978. The History of Sexuality, Vol.1. New York: Vintage Books.

Fraenkel, Jon, and Stewart Firth. 2009. "Fiji's Coup Syndrome." In The 2006 Military Takeover in Fiji: A Coup to End All Coups? edited by Jon Fraenkel, Stewart Firth, and Brij V. Lal, 449-58. Canberra: ANU E Press. http://press-files.anu. edu.au/downloads/press/p7451/pdf/ch31.pdf.

Gates, Henry L. 1991. "Critical Fanonism.” Critical Inquiry 17 (3): 457-70. doi:10.1086/448592.

Guha, Ramachandra. 1999. Savaging the Civilized: Verrier Elwin, His Tribals, and India. Chicago: University of Chicago Press.

— 2007. India After Gandhi: The History of the World's Largest Democracy. New York: Harper.

Guha, Ranajit. 1982. "On Some Aspects of the Historiography of Colonial India." In Subaltern Studies: Writings on South Asian History and Society I, edited by Ranajit Guha, 1-8. Delhi: Oxford University Press.

Hansen, Thomas B. 2012. Melancholia of Freedom: Social Life in an Indian Township in South Africa. Princeton: Princeton University Press.

Hardy, Tim. 2009. The Reluctant Imperialist: An Adventurous Life in Colonial Malaya, Africa, Fiji and Hong Kong. Singapore: Marshall Cavendish Editions. 
Hau'ofa, Epeli. 1993. "Our Sea of Islands.” In A New Oceania: Rediscovering Our Sea of Islands, edited by Eric Waddell, Vijay Naidu, and Epeli Hau'ofa, 2-16. Suva: University of the South Pacific and Beake House.

Herder, Johann G. v. (1800) 1966. Outlines of a Philosophy of the History of Man. New York: Bergman.

Hobbes, Thomas. (1651) 1982. Leviathan. New York: Penguin Classics.

Ibn Khaldun. (1379) 1989. The Muqaddimah: An Introduction to History. Princeton: Princeton University Press.

Ibn Rushd. (1178) 2017. Tahafut Al-Tahafut (The Incoherence Of The Incoherence). Cairo: Sphinx Books.

James, Aaron. 2017. Surfing with Sartre: An Aquatic Inquiry into a Life of Meaning. New York: Doubleday.

Kahin, George McT. 1956. The Asian-African Conference, Bandung, Indonesia, April 1955. Port Washington: Kennikat Press.

Kamm, Henry. 1988. "Fijians Fretting Under One-Man Rule.” New York Times, July 22. Accessed March 05, 2018. http://www.nytimes.com/1988/07/22/ world/fijians-fretting-under-one-man-rule.html.

Kant, Immanuel. (1784) 1991. "Idea for a Universal History with a Cosmopolitan Purpose.” In Kant: Political Writings, edited by Hans S. Reiss. Cambridge: Cambridge University Press.

Kaplan, Martha. 1995. Neither Cargo nor Cult: Ritual Politics and the Colonial Imagination in Fiji. Durham: Duke University Press.

Kaplan, Martha, and John D. Kelly. 2017. "Constituting Common Futures: Reflecting from Singapore about Decolonisation in Fiji." In Bearing Witness: Essays in Honour of Brij V. Lal, edited by Doug Munro and Jack Corbett, 153-76: ANU Press. http://press-files.anu.edu.au/downloads/press/n2516/ $\mathrm{pdf} / \mathrm{ch} 08 . \mathrm{pdf}$.

Kelly, John D. 1998. "Aspiring to Minority and Other Tactics Against Violence in Fiji." In Making Majorities : Constituting the Nation in Japan, Korea, China, Malaysia, Fiji, Turkey, and the United States, edited by Dru C. Gladney, 173-97. Stanford: Stanford University Press.

- 2001. "Fiji's Fifth Veda: Exile, Sanatan Dharm, and Countercolonial Initiatives in Diaspora." In Questioning Ramayanas: A South Asian Tradition, edited by Paula Richman, 329-51. Berkeley: University of California Press. . 2004. "Gordon Was No Amateur: Imperial Legal Strategies in the Colonization of Fiji." In Law and Empire in the Pacific: Fiji and Hawai i, edited by Sally E. Merry and Donald L. Brenneis, 61-100. Santa Fe: School of American Research Press.

- 2005. "Boycotts and Coups, Shanti and Mana in Fiji." Ethnohistory 52 (1): 13-28. doi:10.1215/00141801-52-1-13.

. 2011. "Shanti and Mana: The Loss and Recovery of Culture Under Postcolonial Conditions in Fiji." In Changing Contexts, Shifting Meanings: Transformations of Cultural Traditions in Oceania, edited by Elfriede Hermann, 
235-49. Honolulu: University of Hawaici Press in Association with the Honolulu Academy of Arts.

Kelly, John D., and Martha Kaplan. 2001a. "Peace in Fiji." In Coup: Reflections on the Political Crisis in Fiji, edited by Brij V. Lal and Michael Pretes, 65-68.

Canberra: Pandanus Books and the Research School of Pacific and Asian Studies.

. 2001b. Represented Communities: Fiji and World Decolonization. Chicago: University of Chicago Press.

__ 2008. "Legal Fictions After Empire." In The State of Sovereignty: Territories, Laws, Populations, edited by Douglas R. Howland and Louise White, 169-195. Bloomington: Indiana University Press.

Khan, Aisha. 2004. Callaloo Nation: Metaphors of Race and Religious Identity Among South Asians in Trinidad. Durham: Duke University Press.

Kolff, Dirk H. A. 1990. Naukar, Rajput and Sepoy: The Ethnohistory of the Military Labour Market in Hindustan, 1450-1850. Cambridge: Cambridge University Press.

Lal, Brij V. 2010. In the Eye of the Storm: Jai Ram Reddy and the Politics of Postcolonial Fiji. Canberra: ANU E Press. http://www.oapen.org/search?identifier= 459279.

. (1997) 2011. A Vision for Change: AD Patel and the Politics of Fiji. Canberra: ANU E Press. http://press-files.anu.edu.au/downloads/press/p151821/ pdf/book.pdf?referer $=458$.

_ 2012. Intersections: History, Memory, Discipline. Canberra: ANU E Press. Accessed February 15, 2018. http://press.anu.edu.au/?p=209021.

Locke, John. (1689) 1988. Two Treatises of Government. Edited by Peter Laslett. Cambridge: Cambridge University Press.

Marriott, McKim. 1976. "Hindu Transactions: Diversity without Dualism." In Transaction and Meaning: Directions in the Anthropology of Exchange and Symbolic Behavior, edited by Bruce Kapferer, 109-42. Philadelphia: Institute for the Study of Human Issues.

Mauss, Marcel. 1973. “Techniques of the Body." Economy and Society 2 (1): 70-88. doi:10.1080/03085147300000003.

May, Simon J. 2014. "A Fighting People? Fijian Service in the British Army and the Production of Race and Nation." PhD dissertation, Department of Anthropology, University of Chicago.

Mazower, Mark. 2009. No Enchanted Palace: The End of Empire and the Ideological Origins of the United Nations. Princeton: Princeton University Press.

Mazzarella, William. 2013. Censorium: Cinema and the Open Edge of Mass Publicity. Durham: Duke University Press.

McGranahan, Carole. 2010. Arrested Histories: Tibet, the CIA, and Memories of a Forgotten War. Durham: Duke University Press.

Michaud, Jean. 2006. Historical Dictionary of the Peoples of the Southeast Asian Massif. Lanham: Scarecrow Press. 
Montesquieu, Charles de. (1748) 1989. The Spirit of the Laws. Edited by Anne M. Cohler, Basia C. Miller, and Harold Stone. Cambridge: Cambridge University Press.

Munasinghe, Viranjini. 2001. Callaloo or Tossed Salad? East Indians and the Cultural Politics of Identity in Trinidad. Ithaca: Cornell University Press.

Munro, Doug. 1990. "The Origins of Labourers in the South Pacific: Commentary and Statistics." In Labour in the South Pacific, edited by Clive Moore, Jacqueline Leckie, and Doug Munro, xxxix-li. Townsville: James Cook University of North Queensland.

Naipaul, Vidiadhar S. 1999. Between Father and Son: Family Letters. New York: Vintage Books.

Nehru, Jawaharlal. 1946. The Discovery of India. London: Meridian Books. - (1952) 2006. "Jawaharlal Nehru's Speech at the Opening Session of the Scheduled Tribes and Scheduled Areas Conference at New Delhi on 7 June, 1952." In Documents of North-East India, Vol.1: North-East India - A Bird'sEye View, edited by S. K. Sharma and Usha Sharma, 115-21. New Delhi: Mittal Publications.

Reeves, Paul, Tomasi R. Vakatora, and Brij V. Lal. 1996. The Fiji Islands: Towards a United future. Report of the Fiji Constitution Review Commission 1996. Suva: Government Printer.

Rousseau, Jean-Jacques. (1762) 1968. The Social Contract. London: Penguin Classics.

Sahlins, Marshall D. 1976. Culture and Practical Reason. Chicago: University of Chicago Press.

Sanadhya, Totaram. (1922) 1991. "The Story of the Haunted Line.” In My TwentyOne Years in the Fiji Islands, edited by John D. Kelly, 115-27. Suva: The Fiji Museum.

Sartre, Jean-Paul. (1957) 1968. Search for a Method. New York: Vintage Books.

Saunders, Cheryl. 1997. "The Constitutional Preamble." In Fiji and the World: Research Papers of the Fiji Constitution Review Commission Vol. 2, edited by Brij V. Lal and Tomasi R. Vakatora, 260-68. Suva: University of the South Pacific.

Scott, James C. 2009. The Art of Not Being Governed: An Anarchist History of Upland Southeast Asia. New Haven: Yale University Press.

Spykman, Nicholas J. 1944. The Geography of the Peace. New York: Harcourt Brace.

Tambiah, Stanley J. 1996. Leveling Crowds: Ethnonationalist Conflicts and Collective Violence in South Asia. Berkeley: University of California Press.

Tan, See S., and Amitav Acharya. 2008. Bandung Revisited: The Legacy of the 1955 Asian-African Conference for International Order. Singapore: NUS Press.

Thomas, Nicholas. 1991. Entangled Objects: Exchange, Material Culture, and Colonialism in the Pacific. Cambridge: Harvard University Press.

Trnka, Susanna. 2008. State of Suffering: Political Violence and Community Survival in Fiji. Ithaca: Cornell University Press. 
van Schendel, Willem. 2005. "Geographies of Knowing, Geographies of Ignorance: Jumping Scale in Southeast Asia." In Locating Southeast Asia: Geographies of Knowledge and Politics of Space, edited by Paul H. Kratoska, Remco Raben, and Henk Schulte Nordholt, 275-307. Singapore: Singapore University Press. Veblen, Thorstein. (1917) 1998. The Nature of Peace. New Brunswick: Transaction Publishers.

Weeraratna, Senaka. 2014. "Sri Lanka Must Claim Observer Status at Panchsheel Commemorative Events in Beijing." Posted on Lankaweb on June 26, 2014. Accessed March 03, 2018. http://www.lankaweb.com/news/items/2014/06/ 26/sri-lanka-must-claim-observer-status-at-panchsheel-commemorative-even ts-in-beijing/.

Wells, Herbert G. 1920. The Outline of History: Being a Plain History of Life and Mankind. New York: Macmillan.

Williams, Brackette F. 1991. Stains on My Name, War in My Veins: Guyana and the Politics of Cultural Struggle. Durham: Duke University Press.

Wright, Richard. (1956) 1995. The Color Curtain: A Report on the Bandung Conference. Jackson: Banner Books.

Zaidi, A. M. 1985. Congress, Nehru, and the Second World War. New Delhi: Indian Institute of Applied Political Research. 